Jurnal Indonesia Sosial Teknologi: p-ISSN: 2723 - 6609

e-ISSN : 2745-5254

Vol. 2, No. 1 Januari 2021

\title{
PENGARUH JUMLAH PERUSAHAAN, MODAL DAN NILAI PRODUKSI TERHADAP PENYERAPAN TENAGA KERJA PADA INDUSTRI KECIL DAN KERAJINAN RUMAH TANGGA DI KABUPATEN TUBAN
}

\section{Rosalia Agista Nur Wulansari}

Universitas Pembangunan Nasional Veteran, Jawa Timur

Email: rosaliaagistanurws@gmail.com

\begin{abstract}
The purpose of this study is that the variabels of the company amount, capital and productions value have a significant effect on labor absorption in small industries and household craft in Tuban Regency. In study using multiple regression analyss with the help of the SPSS 22.0 program to process research data. The population is 20 districts and the sample is taken randomly by taking 2 districts. The test results show that the variabel of the number of companies, capital and production value have a significant effect on labor absorption in small industries and household crafts in Tuban Regency. And the most dominant variabel is the number of companies, because the increasing number of companies will increase the number of workers needed. This study uses multiple linear regression analysis with classical assumption testing, coefficient of determination, f test and t test.
\end{abstract}

Keyword : Capital; Number of Businesses; Production Value

\begin{abstract}
Abstrak
Tujuan penelitian ini agar variabel julah perusahaan, modal dan nilai produksi memiliki pengaruh yang signifikan terhadap penyerapan tenaga kerja pada industry kecil dan kerajinan rumah tangga di Kabupaten Tuban. Dalam penelitian ini menggunakan analisis regresi berganda dengan bantuan program SPSS 22.0 untuk mengolah data penelitian. Populasi 20 kecamatan dan untuk sampel diambil secara acak dengan mengambil 2 kecamatan. Hasil penelitian ini menunjukan bahwa variabel jumlah perusahaan, modal dan nilai produksi memiliki pengaruh signifikan terhadap penyerapan tenaga kerja pada industry kecil dan kerajinan rumah tangga di Kabupaten Tuban. Dan variabel yang paling dominan adalah jumlah perusahaan, karena semakin bertambahnya jumlah perusahaan maka akan semakin bertambahnya jumlah tenaga kerja yang dibutuhkan. Penelitian ini menggunakan analisis regresi linier berganda dengan pengujian asumsi klasik, koefisen determinasi, uji f dan uji t.
\end{abstract}

Kata kunci: Capital; Number of Businesses; Production Value. 


\section{Pendahuluan}

Permasalahan penyerapan tenaga kerja tidak dapat dipungkiri menjadi inti bagi pembangunan daerah. dan lapangan kerja sebagai penghasilan bagi masyarakat. Kecil atau besarnya hasil dari bekerja menjadi tolak ukur kesejahteraan keluarga tersebut, karena pada kesempatan kerja tersebut angkatan kerja dapat mengeluarkan keahlian yang dimiliki. (Hasibuan, 2005) Prose pembangunan suatu negara sering dikaitan dengan proses industrialisasi. Dan tidak dipungkiri dalam proses industrialisasi banyak factor yang menjadi hambatan yaitu salah satunya ketika jumlah penduduk semakin banyak maka akan terjadi ketimpangan dalam mendapatkan lapangan pekerjaan. (Jawa timur adalah provinsi yang memiliki jumlah penduduk sebesar 39,29 juta jiwa dan penduduk yang ada pada kabupaten tuban adalah 1,16 juta jiwa. (BPS Jawa Timur, 2017). Dengan jumlah penduduk yang ada di Jawa Timur sudah pasti tersebar diberbagai kota dan daerah seperti di Kabupaten Tuban. Kabupaten Tuban Provinsi Jawa Timur terdapat 20 kecamatan diantaranya Kenduruan, Bangilan, Senori, Singgahan, Montong, Parengan, Soko, Rengel, Grabagan, Plumpang, Widang, Palang, Semanding, Tuban, Jenu, Merakurak, Kerek, Tambakboyo, Bancar. (BPS KabTuban, 2014).

Berdasarkan penelitian dari (Fauziah, 2015) mengenai analisis penyerapan tenaga kerja pada industry kecil dan menengah di Kota paluu memberikan hasil bahwa nilai investasi, nilai produksi dan UMP memiliki pengaruh yang signifikan positif terhadap penyerapan tenaga kerja pada industry kecil dan menengah di Kota Palu. Penelitian dari (Bustam, 2017) tentang pengaruh jumlah unit, PDB, dan investasi UMKM terhadap penyerapan tenaga kerja di Indonesia memberikan hasil bahwa jumlah unit, PDB dan investasi memiliki pengaruh signifikan terhadap penyerapan tenaga kerja, Tetapi pada penelitian (Akhmad Syaifuddin Fahlevi, 2016) tentang pengaruh jumlah usaha dan nilai produksi terhadap penyerapan tenaga kerja pada industry kecil menengah di Kabupaten Sidoarjo, memberikan hasil bahwa jumlah usaha tidak berpengaruh singnifikan terhadap penyerapan tenaga kerja sedangkan nilai produksi berpengaruh signifikan terhadap penyerapan tenaga kerja. Adapun factor yang mempengaruhi penyerapan tenaga kerja adalah jumlah perusahaan, modal dan nilai produksi terhadap penyerapan tenaga kerja pada industry kecil dan kerajinan rumah tangga di Kab Tuban.

Industri adalah seluruh bentuk kegiatan ekonomi yang mengolah bahan baku dan memanfaatkan sumber daya industry sehingga menghasilkan barang yang mempunyai nilai tambah atau manfaat lebih tinggi, termasuk jasa industry. (UU No 3 Tahun 2014 Tentang Perindustrian). Ciri khas dari industri kecil adalah dimiliki oleh perorangan dan perorangan tersebut juga menjadi pemilik utama atau usaha. (Kuncoro, 2000).

Dari pengertian diatas maka industry mencakup segala kegiatan produksi yang memproses pembuatan bahan bahan mentah menjadi bahan setengah jadi maupun barang jadi atau kegiatan yang dapat mengubah dari barang yang tidak memiliki nilai menjadi barang yang bernilai tinggi. Ciri-ciri industri kecil adalah modal bersumber dari uang pribadi atau keluarga terdekat, tidak memiliki batas waktu operasional, pada umumnya unit usaha tidak memiliki ijin, teknologi masih bersifat sederhana, dapat berubah menjadi sektor usaha lain, tenaga kerja berasal dari kerabat atau pemodal bisa merangkap sebagai tenaga kerja. (Ichwan, 2015). 
Secara umum jumlah tenaga kerja memiliki pngaruh yang signifikan terhadap penyerapan tenaga kerja, karena semkain meningkatnya jumlah usaha maka penyerapan tenaga kerja akan sangat dibutuhkan (Saputri, 2018). Menurut Badan Pusat Statistik jumlah perusahaan ialah unit yang melakukan kegiatan yang dilakukan oleh perseorangan atau rumah tangga maupun suatu badan dan memiliki kewenangan yang ditentukan berdasarkan kebenaran lokasi bangunan fisik dan wilayah operasinya. Selain jumlah perusahaan factor lain yang mempengaruhi penyerapan tenaga kerja adalah modal, modal memiliki segi pandang luas dan sempit. Dalam arti sempit modal dimaksud dengan uang atau biaya yang dikeluarkan, dan dalam artian luas modal adalah keseluruhan dari sumber ekonomi (Sarwanti, Hasiholan, \& Wulan, 2017).

Modal memiliki tujuan untuk menaikkan produksi yang jauh lebih tinggi sehingga menjadikan surplus lebih besar. (Haryani, 2002). Riyadh Rahmad Prabandana melakukan penelitian tentang pengaruh modal, nilai produksi dan tingkat upah terhadap penyerapan tenaga kerja industri kecil di Kabupaten Sukoharjo menghasilakan hasil variable modal, nilai produksi dan tingkat upah memiliki keterkaitan dengan penyerapan tenaga kerja.

Produksi adalah barang yang awalnya tidak memiliki nilai guna atau nilai secara finasial kemudian diolah untuk menghasilkan barang yang bernilai tinngi atau mempunyai makna (Lesmana \& Affandi, 2013). Nilai produksi merupakan hal yang penting terhadap penyerapan tenaga kerja pada Kabupaten Tuban. Keseluruhan dari jumlah industri disebut dengan jumlah produksi. Meningkat dan menurunya hasil produksi dari industri yang terkait (Sumarsono, 2003). melakukan penelitian tentang pengaruh jumlah usaha dan nilai produksi terhadap penyerapan tenaga kerja pada industry kecil dan menengah di Kabupaten Sidoarjo, menghasilkan variable jumlah unit usaha dan nilai produksi secara bersamaan memengaruhi penyerapan tenaga kerja di Kabupaten Sidoarjo (Akhmad Syaifuddin Fahlevi, 2016).

Table 1.1 Jumlah Perusahaan, Modal, Nilai Produksi dan Tenaga Kerja Pada Industri Kecil dan Kerajinan Rumahtangga di Kabupaten Tuban

\begin{tabular}{ccrrr}
\hline Tahun & $\begin{array}{c}\text { Jumlah } \\
\text { Perusahaan }\end{array}$ & Modal & Nilai Produksi & $\begin{array}{c}\text { Tenaga } \\
\text { Kerja }\end{array}$ \\
\hline 2003 & 14.973 & 19.459 .847 & 662.396 .719 & 42.119 \\
\hline 2004 & 15.068 & 19.836 .547 & 673.185 .050 & 42.795 \\
\hline 2005 & 15.129 & 22.721 .303 & 705.517 .746 & 43.021 \\
\hline 2006 & 15.193 & 223.683 .814 & 736.552 .079 & 43.408 \\
\hline 2007 & 15.274 & 239.286 .529 & 767.095 .359 & 43.651 \\
\hline 2008 & 15.28 & 267.907 .564 & 823.430 .079 & 43.735 \\
\hline 2009 & 15.518 & 293.143 .364 & 845.906 .829 & 44.509 \\
\hline 2010 & 15.602 & 442.191 .656 & 1.083 .846 .375 & 44.971 \\
\hline 2011 & 15.698 & 592.419 .656 & 1.372 .188 .375 & 45.078 \\
\hline 2012 & 15.782 & 594.133 .507 & 1.375 .746 .230 & 45.173 \\
\hline
\end{tabular}




\begin{tabular}{lllll}
\hline 2013 & 15.857 & 595.857 .567 & 1.382 .052 .512 & 45.462 \\
\hline 2014 & 16.182 & 601.130 .682 & 1.426 .428 .308 & 46.319 \\
\hline
\end{tabular}

Sumber: Badan Pusat Statistik Kab Tuban

Pengaruh Jumlah Perusahaan, Modal dan Nilai Produksi Terhadap Penyerapan Tenaga Kerja Pada Industri Kecil dan Kerajinan Rumah Tangga di Kab Tuban.

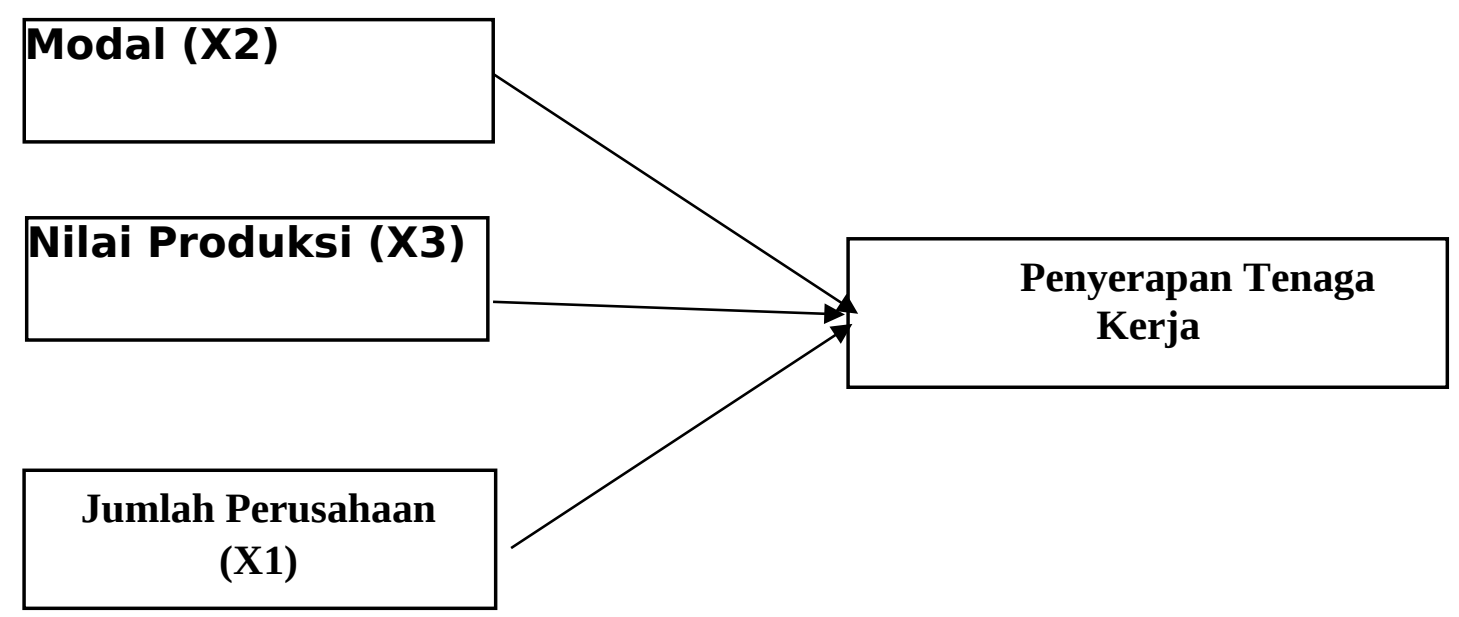

\section{Manfaat Penelitian}

Manfaat yang diharapkan dalam penelitian ini adalah :

1. Penelitian ini diharapkan mampu memperkaya ragam penelitian mengenai penyerapan tenaga kerja pada industri kecil dan kerajinan rumah tangga di Kabupaten Tuban dan dapat menambah wawasan mengenai industri kecil, nilai produksi dan penyerapan tenaga kerja pada industri kecil dan kerajinan rumah tangga, khususnya mahasiswa.

2. Penelitian ini diharapkan dapat memberikan informasi kepada Dinas Koperasi, Pelaku usaha industri kecil dan kerajinan rumah tangga, Perindustrian dan Perdagangan Kabupaten Tuban untuk memperhatikan mengenai perkembangan industri kecil dan kerajinan rumah tangga yang ada di Kabupaten Tuban.

Tujuan dilakukannya penelitian ini sebagai berikut :

1. Mengetahui ada atau tidaknya pengaruh signifikan variabel jumlah perusahaan terhadap penyerapan tenaga kerja

2. Mengetahui ada atau tidaknya pengaruh signifikan variabel modal terhadap penyerapan tenaga kerja.

3. Mengetahui ada atau tidaknya pengaruh signifikan variabel nilai produksi terhadap penyerapan tenaga kerja.

\section{Metode Penelitian}

\section{Populasi Dan Sampel}

Populasi adalah seluruh jumlah kecamatan yang ada di Kab Tuban berjumlah 20 kecamatan. Sedangkan untuk sampel mengambil 2 kecamatan yaitu kecamatan Jatirogo 
Dan Bangilan dengan jumlah 20 responden yang mewakili keseluruhan komoditi industry kecil dan kerajinan rumah tangga di Kab Tuban. Lokasi Penelitian Industri kecil dan kerajinan rumah tangga di Kabupaten Tuban. Analisis Deskriptif Metode deskripftif kualitatif adalah analisi yang menjelaskan dengan kata - kata bukan dengan angka.

Tujuan analisis ini digunakan utuk menjelaskan tentang fakta fakta yang dilapangan denan teori, konsep - konsep yang ada pada literature terkait. Metode Deskriptif Kuantitatif Metode dengan menggunakan perhitungan jumlah perusahaan, modal dan nilai produksi terhadap penyerapan tenaga kerja pada industry kecil dan kerajinan rumah tangga di Kabupaten Tuban. Metode analisa berbentuk angka- angka. Regresi Linier Berganda Pada penelitian ini menggunakan alat analisis regresi linier berganda, diolah dengan Spss sebagai alat untuk analisis data. Regresi linier berganda ialah alat yang digunakan untuk menganalisis variable-variabel apakah memiliki hubungan dengan penyerapan tenaga kerja di Kabupaten Tuban. Jenis data yang digunakan adalah data sekunder yang diperoleh dari Badan Pusat Statistik, Dinas Perindustrian Kab Tuban, wawancara dengan responden.

Rumus rehresi linier berganda sebagai berikut:

$$
\begin{aligned}
& \mathrm{Y}=\mathrm{a}+\mathrm{b} 1 \mathrm{x} 1+\mathrm{b} 2 \mathrm{x} 2+\mathrm{e} \\
& \mathrm{Y}=\text { tenaga kerja } \\
& \mathrm{a}=\text { konstanta } \\
& \mathrm{b} 1, \mathrm{~b} 2, \mathrm{~b} 3=\text { koefisien regresi } \\
& \mathrm{X} 1=\text { Jumlah perusahaan } \\
& \mathrm{X} 2=\text { modal } \\
& \mathrm{X} 3=\text { Nilai produksi }
\end{aligned}
$$

\begin{tabular}{|c|c|c|c|c|c|c|}
\hline \multirow{2}{*}{\multicolumn{2}{|c|}{ Model }} & \multicolumn{2}{|c|}{$\begin{array}{l}\text { Unstandardized } \\
\text { Coefficients }\end{array}$} & \multirow{2}{*}{\begin{tabular}{l}
$\begin{array}{l}\text { Standardiz } \\
\text { ed } \\
\text { Coefficie } \\
\text { nts }\end{array}$ \\
\multicolumn{1}{c}{ Bet } \\
a
\end{tabular}} & \multirow[t]{2}{*}{$\mathrm{t}$} & \multirow{2}{*}{$\begin{array}{c}\text { Sig } \\
\cdot\end{array}$} \\
\hline & & B & Std. Error & & & \\
\hline \multirow[t]{4}{*}{1} & (Constant) & .457 & 1.026 & & .446 & .662 \\
\hline & JP & 3.266 & .714 & .908 & 4.572 & .000 \\
\hline & $\mathrm{M}$ & $-8.924 \mathrm{E}-5$ & .000 & -.124 & -.753 & .463 \\
\hline & NP & $3.341 \mathrm{E}-5$ & .000 & .027 & .135 & .894 \\
\hline
\end{tabular}

\section{Hasil Regresi Berganda \\ Uji Asumsi Klasik}

Didalam penelitian ini terbebas dari uji autokorelasi, uji multikolinearitas dan uji heterokedastisitas.

\section{Koefisien Regresi}

Table Coefficientsa 
a. Dependent Variable: TK

Signifikasi 5\%, maka dapat dituliskan dengan rumus sebagai berikut :

$\mathrm{Y}=0,457+3,266 \mathrm{X} 1+(-8,924) \mathrm{X} 2+3,341 \mathrm{X} 3+\mathrm{e}$

$\mathrm{a}=0,457$ artinya apabila variable independen yaitu jumlah perusahaan, modal dan nilai produksi sama dengan nol maka penyerapan tenaga kerja yang ada di Kabupaten Tuban mengalami kenaikan $0,457 \%$

b1 = 3,266 artinya apabila jumlah perusahaan berubah atau naik satu satuan maka penyerapan tenaga kerja juga akan naik sebesar 3,266 dengan variable lain tetap b2 = -8,924 artinya apabila modal berubah atau naik satu satuan maka akan mengalami kenaikan sebesar 8,924 dengan variable lain tetap

b3 = 3,341 artinya apabila nilai produksi berubah atau naik satu satuan maka akan mengalami kenaikan sebesar 3,341\% dengan variabel lain tetap.

\section{Koefisien Determinasi}

Table Model Summaryb

\begin{tabular}{|c|c|c|c|c|}
\hline Model & $\mathrm{R}$ & R Square & $\begin{array}{l}\text { Adjusted } \\
\mathrm{R} \\
\text { Square } \\
\end{array}$ & $\begin{array}{l}\text { Std. Error of } \\
\text { the } \\
\text { Estimate }\end{array}$ \\
\hline 1 & $\begin{array}{l}.862 \\
a\end{array}$ & .743 & .694 & $\begin{array}{l}1.8775 \\
8\end{array}$ \\
\hline
\end{tabular}

a. Predictors: (Constant), NP, M, JP

b. Dependent Variable: TK

Menunjukan tentang keakuratan hubungan antara variable independent dengan variable dependent. Berikut hasil pengolahan data mengunakan SPSS 22.0 Hasil estimasi diperoleh $\mathrm{R}$ square sebesar 0,743 yang artinya 74,3\% tingkat penyerapan tenaga kerja pada sector industry kecil dan kerajinan rumah tangga di Kabupaten Tuban dapat dijelaskan dengan variabel jumlah perusahaan, modal dan nilai produksi. Sedangkan sisanya dipengaruhi oleh variabel lainnya yaitu 25,7\%.

\section{Pengujian Hipotesis}

ANOVAa

\begin{tabular}{|c|c|c|c|c|c|c|}
\hline \multicolumn{2}{|c|}{ Model } & $\begin{array}{l}\text { Sum of } \\
\text { Squares }\end{array}$ & $\begin{array}{l}d \\
f\end{array}$ & $\begin{array}{l}\text { Mean } \\
\text { Square }\end{array}$ & $\mathrm{F}$ & Sig. \\
\hline \multirow[t]{3}{*}{1} & Regression & 162.795 & 3 & 54.265 & 15.39 & .000 \\
\hline & Residual & 56.405 & 16 & 3.525 & & \\
\hline & Total & 219.200 & 19 & & & \\
\hline
\end{tabular}

a. Dependent Variable: TK

b. Predictors: (Constant), NP, M, JP

Uji F digunakan untuk mengetahui apakah variabel independent memiliki pengaruh secar simultan atau tidak terhadap variabel dependent. 
Hasil yang diperoleh dari menunujukan bahwa nilai Fhitung sebesar 15,393 dengan signifikasi 0,000. Nilai Fhitung dengan df1 $=\mathrm{k}-1=4-1=3$, df2 $=\mathrm{n}-\mathrm{k}=16$. Maka diperoleh nilai Ftabel sebesar 3,63 dan signifikasi yang digunakan adalah 5\% atau 0,05. Berarti Fhitung 15,393 > Ftabel (3,63) dan signifikan 0,000 < 0,05. Dengan demikian maka Ho ditolak dan Ha diterima. Maka hipotesis menyatakan bahwa ada pengaruh secara signifikan antara variabel jumlah perusahaan, modal dan nilai produksi terhadap penyerapan tenaga kerja pada sector industry kecil dan kerajinan rumah tangga di Kabupaten Tuban.

\section{Uji parsial ( uji t )}

Uji t digunakan untuk menguji secara parsial apakah variabel bebas berpengaruh secara parsial terhadap variabel terikat $\mathrm{Y}$ dengan asumsi variabel lain. Nilai t hitung dibandingkan dengan nilai t table pada tingkat derajat keyakinan 5\%. Apabila diperoleh hasil nilai $\mathrm{t}$ hitung variabel bebas>nilai $\mathrm{t}$ table, maka Ho ditolak yang berarti variabel bebas secara parsial berpengaruh signifikan terhadap penyerapan tenaga kerja pada industry kecil dan kerajinan rumah tangga di Kabupaten Tuban. Begitupun sebaliknya apabila t hitung variabel bebas < dari t table maka Ho diterima berarti variabel bebas secara parsial tidak memiliki hubungan secara signifikan terhadap penyerapan tenaga kerja pada industry kecil dan kerajinan rumah tangga di Kabupaten Tuban.

\section{Hasil dan Pembahasan}

\section{Pengaruh Jumlah Perusahaan Dengan Penyerapan Tenaga Kerja Pada Sektor Industi Kecil Dan Kerajinan Rumah Tangga Di Kabupaten Tuban}

Menurut (Sulistiawati, 2013), jumlah perusahaan memiliki pengaruh terhadap penyerapan tenaga kerja dan mempunyai keterkaitan yang positif. Karena semakin meningkatnya jumlah perusahaan akan meningkatkan penyerapan teanaga kerja. Begitupun sebaliknya, apabila jumlah perusahaan menurun akan mengurangi jumlah tenaga kerja.

Berdasarkan hasil perhitungan pengaruh jumlah perusahaan dengan penyerapan tenaga kerja diperoleh hasil t sig 0,00 > 0,05 berarti memiliki hubungan yang positif atau penyerapan tenaga kerja dipengaruhi oleh jumlah perusahaan.

Hasil penelitian dari (Saputri, 2018) tentang analisis pengaruh jumlah unit usaha, investasi dan upah minimum terhadap penyerapan tenaga kerja pada sector industi pengolahan besar dan sedang di Kota Surabaya Tahun 2005 - 2014 menyatakan bahwa jumlah unit usaha memiliki pengaruh positif terhadap penyerapan tenaga kerja di Kota Surabaya relevan dengan penelitian ini.

Berdasarkan hasil penelitian diperoleh data t hitung jumlah perusahaan sebesar 4,572 dengan signifikasi sebesar 0,000. ( $\mathrm{df}=\mathrm{n}-\mathrm{k}$ ), $\mathrm{df}=20-4=16$ dengan taraf signifikasi 2 sisi adalah 0,025 maka t table sebesar 2,119. Oleh karena itu 4,572 > 2,119 atau nilai signifikan 0,000 < 0,05 maka Ho ditolak Ha diterima. Secara parsial maka X1 jumlah perusahaan berpengaruh secara positif dan signifikan terhadap penyerapan tenaga kerja di Kabupaten Tuban. Karena dengan jumlah perusahaan yang semakin meningkat maka akan menambah penyerapan teanga kerja. 


\section{Pengaruh Modal Dengan Penyerapan Tenaga Kerja Pada Sektor Industri Kecil Dan Kerajinan Rumah Tangga Di Kabupaten Tuban}

Modal kerja adalah modal lancar yang meliputi seluruh uang tunai dan persediaan barang yang digunakan utuk kegiatan proses produksi oleh pengusaha. Semakin tinggi modal maka sakan menambah penyerapan tenaga kerja dan modal kerja berpengaruh positif dengantenaga kerja. (Haryani, 2002)

Hasil penelitian dari Riyadh tentang pengaruh modal, nilai investasi dan tingkat upah terhadap penyerapan tenaga kerja industry kecil di Kabupaten Sukhoharjo menyatakan bahwa modal tidak berpengaruh dengan penyerapan tenaga kerja, dan penelitian tersebut relevan dengan penelitian ini.

Hasil penelitian ini menunjukan bahwa t hitung $-0,753<2,119$ atau nilai signifikasi 0,463> 0,05, maka Ho diterima dan Ha ditolak. Ini berarti modal secara parsial tidak berpengaruh terhadap penyerapan tenaga kerja pada industry kecil dan kerajinaan rumah tangga di Kabupaten Tuban. Modal bertambah atau berkurang tidak berpengaruh terhadap penyerapan tenaga kerja karena modal bertambah besar digunakan untuk membeli alat alat yang lebih canggih untuk proses produksi ketimbang untuk menambah tenaga kerja.

\section{Pengaruh Nilai Produksi Terhadap Penyerapan Tenaga Kerja Pada Sektor Industri Kecil Dan Kerajinan Rumah Tangga Di Kabupaten Tuban}

Nilai produksi yaitu jumlah total barang yang diproduksi oleh industri atau perusahaan tersebut. Tinggi rendahnya permintaan barang yang diminta oleh pasar akan hasil yang diproduksi memiliki keterkaitan jika barang yang diminta mengalami peningkatan.oleh sebab itu semakin meningkatnya barang yang diminta akan menambah jumlah tenaga kerja (Prabandana, 2015).

Hasil penelitian dari (Ichwan, 2015) tentang analisis pengaruh upah, biaya bahan baku, nilai produksi, modal dan lamanya usaha terhadap penyerapan tenaga kerja pada industry kecil kendang sentul di Kota Blitar memiliki pengaruh positif tetapi penelitian tersebut tidak relevan dengan penelitian ini. Hasil dari penelitian ini menunujukan bahwa nilai t hitung sebesar 0,135 < 2,119 dari t table atau memiliki nilai signifikasi sebesar 0,894 > 0,05 yang artinya nilai produksi secara parsial tidak memiliki pengaruh terhadap penyerapan tenaga kerja. Artinya Ho diterima $\mathrm{Ha}$ ditolak.

\section{Kesimpulan}

Berdasarkan hasil analisis dan pembahasan tentang pengaruh jumlah perusahaan, modal dan nilai produksi terhadap penyerapan tenaga kerja pada industry kecil dan kerajinan rumah tangga di Kabupaten Tuban menunjukan kesimpulan. Hasil pengujian menunjukan bahwa variabel independen yang diteliti adalah jumlah perusahaan (X1), modal (X2) dan nilai produksi (X3) memiliki $\mathrm{F}$ hitung dengan probabilitas $<5 \%$ yang secara simultan berpengaruh signifikan terhadap penyerapan tenaga kerja (Y). Sedangakan secara parsial variabel independent jumlah perusahaan (X1) memiliki pengaruh terhadap penyerapan tenaga kerja tetapi variabel modal dan nilai produksi secara parsial tidak meiliki hubungan atau pengaruh terhadap penerapan tenaga kerja. Jumlah perusahaan merupakan variabel yang paling dominan mempengaruhi penyerapan tenaga kerja. Maka dapat diartikan bahwa semakin 
Pengaruh Jumlah Perusahaan, Modal dan Nilai Produksi Terhadap Penyerapan Tenaga Kerja Pada Industri Kecil dan Kerajinan Rumah Tangga di Kab Tuban

bertambahnya jumlah perusahaan makan semakin dibutuhkan tenaga kerja untuk meproduksi barang atau jasa di perusahaan tersebut. 


\section{Bibliography}

AKHMAD SYAIFUDDIN FAHLEVI, A. D. E. (2016). PENGARUH JUMLAH UNIT USAHA DAN NILAI PRODUKSI TERHADAP PENYERAPAN TENAGA KERJA PADA INDUSTRI KECIL MENENGAH DI KABUPATEN SIDOARJO. Jurnal Pendidikan Ekonomi (JUPE), 4(3).

BPS. (2017). Badan Pusat Statistik.

Bustam, Nur Hasanah. (2017). Pengaruh jumlah unit, pdb dan investasi umkm terhadap penyerapan tenaga kerja di indonesia periode 2009-2013. Kutubkhanah, 19(2), 250-261.

Fauziah, Fauziah. (n.d.). Analisis Penyerapan Tenaga Kerja Pada Industri Kecil Dan Menengah (IKM) Di Kota Palu Periode 2000-2013. Katalogis, 3(1).

Haryani, Sri. (2002). Hubungan Industrial di Indonesia. Unit Penerbit dan Percetakan AMP YKPN.

Hasibuan, Ongku Bosar. (2005). Pengaruh Edukasi Perawatan Diri Terhadap Aktivitas Sehari-Hari Pasien Hemodialisa di Rumah Sakit Umum Daerah Dr. Pirngadi Medan.

Ichwan, Muhammad. (2015). ANALISIS PENGARUH UPAH, BIAYA BAHAN BAKU, NILAI PRODUKSI, MODAL DAN LAMANYA USAHA TERHADAP PENYERAPAN TENAGA KERJA PADA INDUSTRI KECIL KENDANG SENTUL DI KOTA BLITAR. Jurnal Kompilasi Ilmu Ekonomi (KOMPILEK), 3(2), 1-11.

Kuncoro, Mudrajat. (2000). Usaha Kecil di Indonesia: Profil, Masalah dan Strategi Pemberdayaan. Sumber, 7, 6-8.

Lesmana, Endoy Dwi Yuda, \& Affandi, Mochammad. (2013). Pengaruh Modal, Tenaga Kerja, Dan Lama Usaha Terhadap Produksi Kerajinan Manik-manik kaca (Studi Kasus Sentra Industri Kecil Kerajinan Manik-Manik Kaca Desa Plumbon Gambng Kec. Gudo Kab. Jombang). Jurnal Ilmiah Mahasiswa FEB, 2(2).

Prabandana, Riyadh Rahmad. (2015). Pengaruh Modal, Nilai Produksi dan Tingkat Upah Terhadap Penyerapan Tenaga Kerja Industri Kecil di Kabupaten Sukoharjo. Universitas Muhammadiyah Surakarta.

Saputri, Miki Dwi. (2018). Analisis Pengaruh Jumlah Unit Usaha, Investasi dan Upah Minimum Terhadap Penyerapan Tenaga Kerja Pada Sektor Industri Pengolahan Besar dan Sedang Di Kota Surabaya Tahun 2005-2014. JEB17: Jurnal Ekonomi Dan Bisnis, 3(01). 
Pengaruh Jumlah Perusahaan, Modal dan Nilai Produksi Terhadap Penyerapan Tenaga Kerja Pada Industri Kecil dan Kerajinan Rumah Tangga di Kab Tuban

Sarwanti, Aprilliyanti, Hasiholan, Leonardo Budi, \& Wulan, Heru Sri. (2017). Pengaruh Modal Usaha, Biaya Bahan Baku dan Tenaga Kerja Terhadap Kinerja Usaha Industri Tahu di Kabupaten Sukoharjo. Journal of Management, 3(3).

Sulistiawati, Rini. (2013). Pengaruh Upah Minimum terhadap Penyerapan Tenaga Kerja dan Kesejahteraan Masyarakat di Provinsi di Indonesia.

Sumarsono, Sony. (2003). Ekonomi Manajemen SDM, ketenagakerjaan. Yogyakarta: Graha Ilmu.

Tuban, BPS. (2014). Badan Pusat Statistik. 